\title{
Biomass Productivity and Physical Properties of the Soil after Cultivation of Cover Plant in the Autumn and Winter
}

\author{
Marcos Cesar Mottin ${ }^{1 *}$, Edleusa Pereira Seidel' ${ }^{1}$, Emerson Fey ${ }^{1}$, Jaqueline Vanelli ${ }^{1}$, \\ André Luiz Alves ${ }^{1}$, Alfredo Richart ${ }^{2}$, Jucenei Fernando Frandoloso ${ }^{1}$, Katiely Aline Anschau ${ }^{1}$, \\ Marcio André Francziskowski ${ }^{1}$ \\ ${ }^{1}$ Center of Agrarian Sciences, State University of the West of Paraná-Unioeste, Campus of Marechal Cândido Rondon, Marechal \\ Cândido Rondon, Paraná, Brazil \\ ${ }^{2}$ School of Agrarian Sciences and Veterinary Medicine, Pontifical Catholic University of Paraná-PUCPR, Toledo Campus, Toledo, \\ Paraná, Brazil \\ Email: ${ }^{\star}$ marcos.c.mottin@hotmail.com
}

How to cite this paper: Mottin, M.C., Seidel, E.P., Fey, E., Vanelli, J., Alves, A.L., Richart, A., Frandoloso, J.F., Anschau, K.A. and Francziskowski, M.A. (2018) Biomass Productivity and Physical Properties of the Soil after Cultivation of Cover Plant in the Autumn and Winter. American Journal of Plant Sciences, 9, 775-788. https://doi.org/10.4236/ajps.2018.94061

Received: February 16, 2018

Accepted: March 17, 2018

Published: March 20, 2018

Copyright $\odot 2018$ by authors and Scientific Research Publishing Inc. This work is licensed under the Creative Commons Attribution International License (CC BY 4.0).

http://creativecommons.org/licenses/by/4.0/

(c) (i) Open Access

\begin{abstract}
The species that can be used as cover plants are many, which makes it difficult to make a choice, since there is no ideal plant, and it is necessary to make a survey of the most favorable species. The objective of this study was to evaluate the biomass productivity of cover crops in autumn and winter (Poaceaea and Fabaceae), and their effects on soil physical properties at different depths. The experimental design was of randomized blocks with subdivided plots, with six replications. The plots consisted of four cover crops in autumn and winter; two Poaceae (black oats and brachiaria) and two Fabaceae (fried pea and white lupine). The subplots were at different depths of evaluations; 0 $0.05 ; 0.05-0.10$ and $0.10-0.15 \mathrm{~m}$ to determine the pore volume and soil density; and 0 to $0.40 \mathrm{~m}$ to resistance to penetration. Were evaluated: dry mass yield; soil surface cover index; volume of macropores, micropores, total porosity; soil density; and soil resistance to penetration. It was verified that the family of plants Fabaceae showed higher dry matter yield $\left(4400 \mathrm{~kg} \cdot \mathrm{ha}^{-1}\right)$, however, the lower soil cover rate $(68.71 \%)$. The highest volume of macropores $\left(0.05 \mathrm{~m}^{3} \cdot \mathrm{m}^{-3}\right)$ and the lowest soil resistance to penetration were observed in the soil cultivated with Poaceae family cover plants, in the respective depths of $0-0.10 \mathrm{~m}$ and $0.05-0.20 \mathrm{~m}$.
\end{abstract}

\section{Keywords}

Green Fertilizers, Soil Porosity, Soil Density, Resistance to Penetration 


\section{Introduction}

Agricultural soils are considered a complex system, because they provide the favorable and necessary conditions so that the seeds of the plants can germinate, develop and reproduce their fruits. In view of this, a favorable physical environment for root growth and development is necessary and of fundamental importance in order to maximize the productivity of the implanted crops. Therefore, the use of managements that do not degrade and/or improve soil structure has received much attention [1]. In a productive system, only chemical properties should be prioritized, but attention must also be paid to the physical properties of the soil, such as: porosity, resistance to penetration, and soil density [2].

The no-tillage system is a technology that is mainly aimed at improving the soil, with objective of preserving the structures. However, this system, when inadequately managed, causes soil compaction. Compaction is characterized by reduced pore volume; reduction of oxygen diffusion rate; increased density; increase in the physical resistance and energy with which the water is trapped in the soil [3]. These factors directly affect root development, and consequently other plant structures, since compaction reduces the volume of soil to be harvested by the roots, as well as the amount of water, air and nutrients available, limiting crop productivity.

Several factors are factors that promote soil compaction, such as lack of crop rotation, reduction of soil organic matter input, intensive traffic of agricultural machines [4], inadequate use of agricultural tires [5], agricultural operations with inadequate soil water contents [6], as well as inadequate weighting of agricultural machines in each type of activity. Compaction is considered to be one of the main causes of degradation of agricultural soils [7].

Soil cover plants are considered an excellent alternative to decompress and improve soil structure, reaching a physical quality satisfactory [8]. The use of decompressing plants composes an important management strategy in intensive production systems [9]. However, the response is dependent on the cultivated plant [10]; because each root system presents a differentiated capacity of development in the soil. However, cover plants with good root development are able to act more uniformly in all soil depths when compared to mechanical systems, contributing more efficiently to the improvement of soil aggregation [11], thus presenting advantages over the use of agricultural implements, which can promote the disintegration of soil structures.

In addition, cover plants promote the removal of nutrients from the subsurface, gradually releasing them on the surface during the decomposition process [12]; formation of biopores with wide variation in size [13] functioning as alternative routes for the growth of the roots [14] and increase in the movement of water and the diffusion of gases in the soil [3]. Another advantage is the high density of roots and periodic renewal becomes this important for the quality and sustainability of the agricultural production system.

The species that can be used as cover plants are many, which makes difficult the best choice [15] because there is no ideal plant, and it is necessary before 
choosing to survey the most favorable species [16]. Information should be sought regarding its adaptation to the region's climate, sowing season, crop cycle, root system development and dry mass production. In this way, it is necessary to choose plant species that overcome physical constraints, as well as, promote the recovery of soil quality, especially when subjected to an intensive system of production.

The soil cover plants of the Poaceae Family are considered to be more efficient in promoting soil structuring in relation to Fabaceae [17]. However, for the first years of implantation of crop successions, the larger soil structuring occurs under the cultivation of Fabaceae [18] plants, which also promote the increase of nitrogen in the soil [19]. However, there is a need for [20]. In order to improve the soil structure, it is necessary to verify the real contribution of these plants in order to maintain or improve soil structure.

Thus, the objective of this work was to evaluate the biomass productivity of cover crops in autumn and winter (Poaceae and Fabaceae), and their effects on soil physical properties at different depths.

\section{Material and Methods}

\subsection{Location, Climate and Soil of the Study Area}

The work was carried out at the Experimental Station Professor Alcibíades Luiz Orlando belonging to the State University of the West of Paraná (UNIOESTE) in the municipality of Entre Rios do Oeste-PR, located at the geographical coordinates $24^{\circ} 40^{\prime} 32.66^{\prime \prime}$ south latitude and $54^{\circ} 16^{\prime} 50.46^{\prime \prime}$ longitude west, to 244 meters of altitude in relation to the level of the sea. According to the climatic classification of Köppen, the climate of the region is subtropical humid mesothermic $(\mathrm{Cfa})$, with hot summers, with average temperatures above $22^{\circ} \mathrm{C}$ and winters with average temperatures and below $18^{\circ} \mathrm{C}$ and an average annual rainfall of 1600 - 1800 millimeters [21]. The soil of the experimental unit is classified as typical Red Eutrophic Oxisol, very clayey texture, smooth undulating relief [22]. Prior to the implantation of the experiment, the area was cultivated with oats in the winter period and corn in succession in the summer.

Prior to the implementation of the experiment, deformed soil samples were collected at the depth of $0-0.20 \mathrm{~m}$ for the determination of the chemical and granulometric characteristics. The chemical analyzes were performed according to the methodology of [23]. The results presented were: $\mathrm{pH}\left(\mathrm{CaCl}_{2}\right)=6.05 ; \mathrm{M} . \mathrm{O} .=$ $24.61 \mathrm{~g} \cdot \mathrm{dm}^{-3} ; \mathrm{P}=2.36 \mathrm{mg} \cdot \mathrm{dm}^{-3} ; \mathrm{Ca}^{2+}=6.61 \mathrm{cmol}_{\mathrm{c}} \mathrm{dm}^{-3} ; \mathrm{Mg}^{2+}=1.77 \mathrm{cmol}_{\mathrm{c}} \mathrm{dm}^{-3}$; $\mathrm{K}^{+}=0.25 \mathrm{cmol}_{\mathrm{c}} \mathrm{dm}^{-3} ; \mathrm{Al}^{3+}=0.00 \mathrm{cmol}_{c} \mathrm{dm}^{-3} ; \mathrm{H}^{+}+\mathrm{Al}^{3+}=2.54 \mathrm{cmol}_{\mathrm{c}} \mathrm{dm}^{-3} \mathrm{eV}$ $(\%)=77.26$. For the granulometric determination, the Bouyoucos densimeter method was used, according to [24]. The results were: $763 \mathrm{~g} \cdot \mathrm{kg}^{-1}$ of clay, 136 $\mathrm{g} \cdot \mathrm{kg}^{-1}$ of silt and $101 \mathrm{~g} \cdot \mathrm{kg}^{-1}$ of sand.

\subsection{Experimental Design, Deployment and Data Collection}

The experimental design was of randomized blocks with subdivided plots, with 
six replications. The plots consisted of four cover crops in autumn and winter; two Poaceae (black oats $\left(\mathrm{T}_{1}\right)$ and brachiaria $\left(\mathrm{T}_{2}\right)$ ) and two Fabaceae (pea forage $\left(\mathrm{T}_{3}\right)$ and white lupine $\left(\mathrm{T}_{4}\right)$ ). The subplots were at different depths of evaluations; $0-0.05\left(\mathrm{P}_{1}\right) ; 0.05-0.10\left(\mathrm{P}_{2}\right)$ and $0.10-0.15\left(\mathrm{P}_{3}\right) \mathrm{m}$ to determine pore volume and soil density; and 0 to $0.40 \mathrm{~m}$ to resistance to penetration. Each plot was composed of $20.0 \mathrm{~m}$ in length and $5.40 \mathrm{~m}$ in width, totalizing $108 \mathrm{~m}^{2}$. The useful area of each plot was calculated by discarding $1 \mathrm{~m}$ from each end and $0.45 \mathrm{~m}$ from each side, totaling $81.0 \mathrm{~m}^{2}$.

Cultivation was carried out mechanically with a plotter on $09 / 05 / 2014$, using $70 \mathrm{~kg} \cdot \mathrm{ha}^{-1}$ of black oats (Avena strigosa S.) grow crops IAPAR 61 Ibiporã; 8 $\mathrm{kg} \cdot \mathrm{ha}^{-1}$ of Brachiaria (Urochloa ruziziensis), with a cultural value of $73.06 \%$; 60 $\mathrm{kg} \cdot \mathrm{ha}^{-1}$ of forage pea (Pisum sativum L.) grow crops IAPAR 83 and $50 \mathrm{~kg} \cdot \mathrm{ha}^{-1}$ of white lupine (Lupinus albus L.). The line spacing used was $0.20 \mathrm{~m}$ for the Poaceae and $0.40 \mathrm{~m}$ for the Fabaceae. No basal fertilization was used.

At 120 days after sowing, the dry mass productivity of the cover plants was evaluated. For this evaluation we used a square sample equivalent to $0.25 \mathrm{~m}^{2}$ randomly placed in each plot, and the plants contained inside were cut close to the ground with pruning shears, and two samples were taken per plot. Samples from each treatment were placed in paper bags and taken to the forced air ventilation oven with a temperature of $65^{\circ} \mathrm{C}$ for a period of 72 hours. When removing material made if the weighing determined the dry mass. Then the cover plants were managed using $3 \mathrm{~kg} \cdot \mathrm{ha}^{-1}$ of glyphosate acid equivalent.

After 25 days of management of the cover trees, the soil cover index was evaluated. For this purpose, a $10 \mathrm{~m}$ long tape was used, which was stretched on both diagonals of each plot. Thus, in each projection of $0.10 \mathrm{~m}$ on the soil surface, the presence or absence of the straw of the covering plants was evaluated [25], being that each point of the projection corresponded to the value of $1 \%$. In each plot, the values of the two diagonals were summed and divided by two, thus obtaining the coverage index of the soil surface.

Also, undisturbed soil samples were collected at two points in each plot for the determination of macroporosity, microporosity, total porosity and soil density. A metal cylinder (Kopecky Ring) of known volume was used. Samples were collected at depths between $0-0.05 ; 0.05-0.10$ and $0.10-0.15 \mathrm{~m}$. After collecting the samples, they were placed for saturation in a tray with a water slide at $2 / 3$ of the height of the metal cylinder for 24 hours.

The samples were then weighed and placed on the tension table with a potential of $-0.006 \mathrm{MPa}$ (light suction), draining the water contained in the macropores. The samples were again weighed and placed in an oven for drying, removing the water contained in the micropores, at $105^{\circ} \mathrm{C}$ for 48 hours, being again weighed. The determinations of macroporosity, microporosity and total porosity were determined according to [24]. Soil density was obtained by the relationship between the dry soil mass and the total volume of the soil collected [24]. 
The soil penetration resistance was evaluated using the Falker digital penetrometer, model PenetroLOG-PGL 1020, with electronic capability for data acquisition, with four measurements per plot. The penetrometer was set to record readings every $0.01 \mathrm{~m}$ depth increment, working at constant penetration velocity. Data from the Falker penetrometer were extracted from the digital memory and analyzed every $0.05 \mathrm{~m}$ depth up to $0.40 \mathrm{~m}$. PenetroLOG Software was used to process the penetration resistance data. At the time of sampling, a soil sample was collected in each plot in the depth of $0-0.20$ and $0.20-0.40 \mathrm{~m}$, for analysis of the moisture content, determined by the standard greenhouse method [24], which presented on average $0.20 \mathrm{~kg} \cdot \mathrm{ka}^{-1}$ of water.

\subsection{Statistical Analyzes}

The data were tabulated and submitted to analysis of variance considering a level of significance of $5 \%$ for the $\mathrm{F}$ test. When significant, the means were compared by the Scheffé test at $5 \%$ probability using the statistical software Sisvar [26]. The contrasts used in the comparison of the means of the treatments by the Scheffé test were: $\mathrm{C}_{1}$ : Comparison between families $\left(+1 \mathrm{~T}_{1}+1 \mathrm{~T}_{2}-1 \mathrm{~T}_{3}-1 \mathrm{~T}_{4}\right) ; \mathrm{C}_{2}$ : Comparison within the family Poaceae $\left(-1 \mathrm{~T}_{1}+1 \mathrm{~T}_{2}\right)$ and $\mathrm{C}_{3}$ : Comparison within the family Fabaceae $\left(-1 \mathrm{~T}_{3}+1 \mathrm{~T}_{4}\right)$. As for the contrasts for the comparison of the depths of the evaluation depths, these were: $\mathrm{C}_{4}$ : Comparison between the depth of $0-0.05 \mathrm{~m}$ versus the depths of $0.05-0.10$ and $0.10-0.15 \mathrm{~m}\left(+2 \mathrm{P}_{1}-1 \mathrm{P}_{2}-1 \mathrm{P}_{3}\right)$ and $\mathrm{C}_{5}$ : Comparison between depths of from $0.05-0.10$ and $0.10-0.15 \mathrm{~m}$ depth $\left(+1 \mathrm{P}_{2}-1 \mathrm{P}_{3}\right)$.

\section{Results and Discussion}

\subsection{Dry Mass Yield and Soil Surface Cover Index}

Checked was a significant effect $(\mathrm{p}<0.05)$ of cover crops on the dry mass productivity and the soil surface coverage ratio. Regarding the physical properties of the soil, there were significant differences $(\mathrm{p}<0.05)$ for the isolated effect of the cover plants and depth of evaluation, as well as the interaction of these factors.

Table 1 shows the mean dry mass and soil cover index as a function of the cultivation of soil cover crops during the autumn and winter period.

Based on Table 2, which shows the values of the dry mass yield and soil cover indexes, it was verified that the highest dry mass yield was obtained under cover crops of the Fabaceae family (Table 2). Obtaining an average yield of 4400 $\mathrm{kg} \cdot \mathrm{ha}^{-1}$; while the Poaceae family showed an average productivity of $3038 \mathrm{~kg} \cdot \mathrm{ha}^{-1}$ (Table 1), that is, the Poaceae showed a productivity of $1361.50 \mathrm{~kg} \cdot \mathrm{ha}^{-1}$ less than the Fabaceae (Table 2). In this way, the plants of the family Fabaceae presented more than $44 \%$ of dry mass, when compared to plants of the family Poaceae.

When analyzing the results found in the literature, it found a contradiction. For [27] as Poaceae were the ones that obtained the highest productivity; while [28] did not obtain significant differences between these families of plants. These 
Table 1. Average dry mass yield and soil cover index as a function of cover crop cultivation in autumn and winter.

\begin{tabular}{|c|c|c|}
\hline \multirow{3}{*}{ Treatment } & Dry mass & Coverage ratio \\
\hline & $\mathrm{kg} \cdot \mathrm{ha}^{-1}$ & $-\%$ \\
\hline & \multicolumn{2}{|c|}{ Poaceae family } \\
\hline Oats $\left(\mathrm{T}_{1}\right)$ & 4966 & 87.83 \\
\hline Brachiaria $\left(T_{2}\right)$ & 1110 & 79.25 \\
\hline \multirow[t]{2}{*}{ Average } & 3038 & 83.54 \\
\hline & \multicolumn{2}{|c|}{ Fabaceae family } \\
\hline Pea $\left(\mathrm{T}_{3}\right)$ & 4083 & 75.50 \\
\hline Lupine $\left(\mathrm{T}_{4}\right)$ & 4716 & 61.92 \\
\hline Average & 4400 & 68.71 \\
\hline
\end{tabular}

Table 2. Values of dry matter yield contrasts and soil surface cover index as a function of cover crop cultivation in autumn and winter.

\begin{tabular}{ccc}
\hline \multirow{2}{*}{ Contrast } & Dry mass & Coverage ratio \\
\cline { 2 - 3 } & $-1361.5^{*}$ & $14.83^{*}$ \\
\cline { 2 - 3 } $\mathrm{C}_{1}$ & $\mathrm{~kg} \cdot \mathrm{ha}^{-1}-$ & $-8.58^{\mathrm{NS}}$ \\
$\mathrm{C}_{2}$ & $-3856^{*}$ & $-13.58^{\star}$ \\
$\mathrm{C}_{3}$ & $633^{\mathrm{NS}}$ & $\%$ \\
\hline
\end{tabular}

Legend: $\mathrm{C}_{1}:\left(+1 \mathrm{~T}_{1}+1 \mathrm{~T}_{2}-1 \mathrm{~T}_{3}-1 \mathrm{~T}_{4}\right) ; \mathrm{C}_{2}:\left(-1 \mathrm{~T}_{1}+1 \mathrm{~T}_{2}\right)$ and; $\mathrm{C}_{3}:\left(-1 \mathrm{~T}_{3}+1 \mathrm{~T}_{4}\right)$. *: Significant by the Scheffé test at $5 \%$ probability, within each parameter evaluated; ${ }^{\text {Ns }}$ : Not significant by the Scheffé test at $5 \%$ probability, within each parameter evaluated.

fluctuations in productivity are due to phytotechnical, edaphic and climatic factors [29] [30].

In the evaluation of the dry mass productivity within the Poaceae family, it was verified that black oats presented a productivity superior to $347 \%$ (Table 1) in relation to brachiaria, with a difference of $3856 \mathrm{~kg} \cdot \mathrm{ha}^{-1}$ (Table 2). In the $\mathrm{Fa}$ baceae family, no significant differences were observed ( $p>0.05$ ) (Table 2). It is worth noting that sowing of the brachiaria was not carried out at the time most appropriate for its development, which affected its dry mass productivity [31].

The highest soil cover index was presented under the cultivation of plants of the Poaceae family (Table 2). A coverage index of $83.54 \%$ was observed; while the Fabaceae presented a coverage index of $68.71 \%$ (Table 1), a difference of approximately $15 \%$ in absolute terms (Table 2 ). This is explained by the higher $\mathrm{C} / \mathrm{N}$ ratio that Poaceae family plants present when compared to Fabaceae [32]. Poaceae are considered to be plants with the highest potential for soil protection due to their lower rate of decomposition [28]. Contributing to the maintenance of soil moisture and protection against erosive effects [33].

The soil surface cover index within the Poaceae family did not present significant differences ( $\mathrm{p}>0.05)$, but for the Fabaceae family significant differences 
were observed $(\mathrm{p}<0.05)$ (Table 2). The forage pea presented a coverage index $13.58 \%$ higher than white lupine in absolute terms; this is due to the growth habit of white lupine being more erect relative to forage pea [28].

\subsection{Physical Properties of Soil}

In Table 3, the average results of the physical properties of the soil at each of the evaluated depths are presented after the cultivation of cover plants of the families Poaceae and Fabaceae. The results of the soil physical properties contrast values are presented in Table 4, where it was verified a higher macroporosity in the soil under treatment with Poaceae $\left(0.05 \mathrm{~m}^{3} \cdot \mathrm{m}^{-3}\right)$ and lower in the treatment with Fabaceae. Therefore, the areas cultivated with Poaceae presented $162.50 \%$ more macropores, when compared to the Fabaceae (Table 3).

Table 3. Mean results of soil physical properties at different evaluation depths as a function of cover crop cultivation in autumn and winter.

\begin{tabular}{|c|c|c|c|c|c|c|c|c|c|c|c|c|}
\hline \multirow{4}{*}{ Treatment } & \multicolumn{3}{|c|}{ Macropores } & \multicolumn{3}{|c|}{ Micropores } & \multicolumn{3}{|c|}{ Total porosity } & \multicolumn{3}{|c|}{ Density } \\
\hline & $0-0.05$ & $0.05-0.10$ & $0.10-0.15$ & $0-0.05$ & $0.05-0.10$ & $0.10-0.15$ & $0-0.05$ & $0.05-0.10$ & $0.10-0.15$ & $0-0.05$ & $0.05-0.10$ & $0.10-0.15$ \\
\hline & \multicolumn{9}{|c|}{$\mathrm{m}^{3} \cdot \mathrm{m}^{-3}$} & \multicolumn{3}{|c|}{$-\mathrm{Mg} \cdot \mathrm{m}^{-3} \longrightarrow$} \\
\hline & \multicolumn{12}{|c|}{ Poaceae family } \\
\hline Oats $\left(\mathrm{T}_{1}\right)$ & 0.18 & 0.12 & 0.08 & 0.40 & 0.40 & 0.42 & 0.57 & 0.53 & 0.51 & 1.13 & 1.22 & 1.30 \\
\hline Brachiaria $\left(\mathrm{T}_{2}\right)$ & 0.19 & 0.12 & 0.08 & 0.37 & 0.41 & 0.43 & 0.57 & 0.55 & 0.50 & 1.17 & 1.30 & 1.37 \\
\hline \multirow[t]{2}{*}{ Average } & & 0.13 & & & 0.40 & & & 0.54 & & & 1.25 & \\
\hline & \multicolumn{12}{|c|}{ Fabaceae family } \\
\hline Peas $\left(\mathrm{T}_{3}\right)$ & 0.10 & 0.07 & 0.05 & 0.49 & 0.47 & 0.51 & 0.59 & 0.54 & 0.56 & 1.22 & 1.30 & 1.47 \\
\hline Lupine $\left(\mathrm{T}_{4}\right)$ & 0.10 & 0.10 & 0.06 & 0.45 & 0.44 & 0.44 & 0.55 & 0.54 & 0.51 & 1.16 & 1.23 & 1.35 \\
\hline Average & & 0.08 & & & 0.47 & & & 0.55 & & & 1.30 & \\
\hline
\end{tabular}

Table 4. Contrast values of soil physical properties at different depths of evaluation as a function of cover crop cultivation in autumn and winter.

\begin{tabular}{|c|c|c|c|c|c|c|c|c|c|c|c|c|}
\hline \multirow{3}{*}{ Contrast } & \multicolumn{3}{|c|}{ Macropores } & \multicolumn{3}{|c|}{ Micropores } & \multicolumn{3}{|c|}{ Total porosity } & \multicolumn{3}{|c|}{ Density } \\
\hline & $0-0.05$ & $0.05-0.10$ & $0.10-0.15$ & $0-0.05$ & $0.05-0.10$ & $0.10-0.15$ & $0-0.05$ & $0.05-0.10$ & $0.10-0.15$ & $0-0.05$ & $0.05-0.10$ & $0.10-0.15$ \\
\hline & & \multicolumn{8}{|c|}{$\mathrm{m}^{3} \cdot \mathrm{m}^{-3}$} & \multicolumn{3}{|c|}{$\longrightarrow \mathrm{Mg} \cdot \mathrm{m}^{-3}$} \\
\hline $\mathrm{C}_{1}$ & $0.08^{*}$ & $0.03^{*}$ & $0.02^{\mathrm{NS}}$ & $-0.08^{*}$ & $-0.05^{\mathrm{NS}}$ & $-0.05^{*}$ & $0.00^{\mathrm{NS}}$ & $0.00^{\mathrm{NS}}$ & $-0.03^{\mathrm{NS}}$ & $-0.04^{\mathrm{NS}}$ & $0.00^{\mathrm{NS}}$ & $-0.07^{\mathrm{NS}}$ \\
\hline Average & & $0.05^{\star}$ & & & $-0.07^{\star}$ & & & $-0.01^{\mathrm{NS}}$ & & & $-0.05^{\mathrm{NS}}$ & \\
\hline $\mathrm{C}_{2}$ & $0.01^{\mathrm{NS}}$ & $0.00^{\mathrm{NS}}$ & $0.00^{\mathrm{NS}}$ & $-0.03^{\mathrm{NS}}$ & $0.01^{\mathrm{NS}}$ & $0.01^{\mathrm{NS}}$ & $0.00^{\mathrm{NS}}$ & $0.02^{\mathrm{NS}}$ & $-0.01^{\mathrm{NS}}$ & $0.04^{\mathrm{NS}}$ & $0.08^{\mathrm{NS}}$ & $0.07^{\mathrm{NS}}$ \\
\hline Average & & $0.00^{\mathrm{NS}}$ & & & $-0.00^{\mathrm{NS}}$ & & & $0.00^{\mathrm{NS}}$ & & & $0.06^{\mathrm{NS}}$ & \\
\hline $\mathrm{C}_{3}$ & $0.00^{\mathrm{NS}}$ & $0.03^{\mathrm{NS}}$ & $0.01^{\mathrm{NS}}$ & $-0.04^{\mathrm{NS}}$ & $-0.03^{\mathrm{NS}}$ & $-0.07^{\mathrm{NS}}$ & $-0.04^{\mathrm{NS}}$ & $0.00^{\mathrm{NS}}$ & $-0.05^{\mathrm{NS}}$ & $-0.06^{\mathrm{NS}}$ & $-0,07^{\mathrm{NS}}$ & $-0.12^{\mathrm{NS}}$ \\
\hline Average & & $0.02^{\mathrm{NS}}$ & & & $-0.05^{\star}$ & & & $-0.03^{\mathrm{NS}}$ & & & $-0.08^{\mathrm{NS}}$ & \\
\hline
\end{tabular}

Legend: $\mathrm{C}_{1}:\left(+1 \mathrm{~T}_{1}+1 \mathrm{~T}_{2}-1 \mathrm{~T}_{3}-1 \mathrm{~T}_{4}\right) ; \mathrm{C}_{2}:\left(-1 \mathrm{~T}_{1}+1 \mathrm{~T}_{2}\right)$ and; $\mathrm{C}_{3}:\left(-1 \mathrm{~T}_{3}+1 \mathrm{~T}_{4}\right){ }^{*}$ : Significant by the Scheffé test at $5 \%$ probability, within each parameter eva-

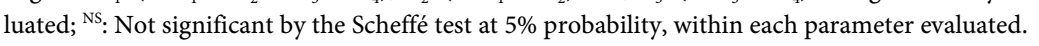


Macroporosity values below $0.10 \mathrm{~m}^{3} \cdot \mathrm{m}^{-3}$ can affect root growth of crops [34]. The highest microporosity of the soil $\left(0.47 \mathrm{~m}^{3} \cdot \mathrm{m}^{-3}\right)$ was observed in the treatment cultivated with the Fabaceae, while the lowest value $\left(0.40 \mathrm{~m}^{3} \cdot \mathrm{m}^{-3}\right)$ was with the Poaceae (Table 3). This behavior was expected because this property is inversely proportional to the soil macroporosity [35].

The effects of the different cover plants on the macroporosity and microporosity of the soil can be attributed to the different forms of the root structures of one of the families. In the Poaceaethe root system is of the fasciculate type and in the Fabaceae pivoting. Therefore, the fasciculate root system promoted a higher volume of macropores as a function of better soil aggregation [36]. Other resultswere reported by [37] that obtained higher macroporosity in the soil after the cultivation of Fabaceae in relation to Poaceae. The authors justify this result as a function of seed decomposition, and the highest volume of micropores in Poaceaeby the production of very fine roots.

In the interaction between the families of cover plants and the evaluated depths, significant differences were observed $(\mathrm{p}<0.05)$ (Table 4). Macroporosity in Poaceae, at depths of $0-0.10 \mathrm{~m}$, presented superiority over the Fabaceae. Thus, it was verified that Poaceae present better results as soil aggregation and macropore formation, since these properties are directly related [38].

Regarding the evaluation of the physical properties of the soil within the families (Table 4), no significant differences $(\mathrm{p}>0.05)$ were observed in the area cultivated with Poaceae. Probably, due to the greater homogeneity of the distribution of the root system of these plants. In Fabaceae the highest microporosity was in the area where there was forage pea cultivation $\left(-0.05 \mathrm{~m}^{3} \cdot \mathrm{m}^{-3}\right)$.

The increase of microporosity when associated to the reduction of macroporosity may be an indication of soil compaction [15]; that is, defragmentation soil aggregate [39]. However, in this study, the increase in microporosity was not accompanied by a reduction of macroporosity.

When assessing the physical properties of the soil at different depths, significant differences $(\mathrm{p}<0.05)$ were observed for macroporosity, total porosity and soil density (Table 5). It was observed a higher volume of macropores (0.05 $\left.\mathrm{m}^{3} \cdot \mathrm{m}^{-3}\right)$, total porosity $\left(0.04 \mathrm{~m}^{3} \cdot \mathrm{m}^{-3}\right)$ and consequently lower soil density $(-0.12$ $\mathrm{Mg} \cdot \mathrm{m}^{-3}$ ) in depth $0-0.05 \mathrm{~m}$, the lowest macroporosity and the highest density in the depth of $0.10-0.15 \mathrm{~m}$ (Table 5).

The highest volume of roots of the plants occurs at the soil surface, being also in this depth the greater deposition of organic material and greater microbial activity, providing greater aggregation and soil structuring [40]. The micropore values were similar at all depths evaluated (Table 5). In general, micropores are more resistant to deformation and little altered by management [41], especially in Oxisols [42].

The soil density above the values of $1.25-1.30 \mathrm{Mg} \cdot \mathrm{m}^{-3}$ are considered critical for most crops in soils with more than $55 \%$ clay [43]. On the other hand, [44] consider as critical density to root growth values above $1.45 \mathrm{Mg} \cdot \mathrm{m}^{-3}$. When the 
Table 5. Contrast values of soil physical properties at different evaluation depths due to cover crop cultivation in autumn and winter.

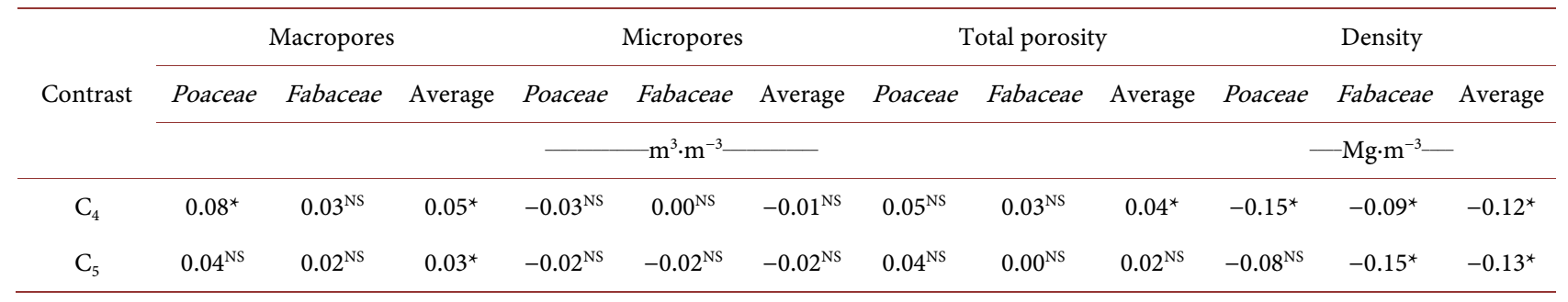

Legend: $\mathrm{C}_{4}:\left(+2 \mathrm{P}_{1}-1 \mathrm{P}_{2}-1 \mathrm{P}_{3}\right)$ and; $\mathrm{C}_{5}:\left(+1 \mathrm{P}_{2}-1 \mathrm{P}_{3}\right){ }^{*}$ : Significant by the Scheffé test at $5 \%$ probability, within each parameter evaluated; ${ }^{\mathrm{NS}}$ : Not significant by the Scheffé test at $5 \%$ probability, within each parameter evaluated.

soil density is higher than $1.30 \mathrm{Mg} \cdot \mathrm{m}^{-3}$, cultivation practices should be carried out to promote the growth of the root system and increase the aggregation [1], which will result in a reduction in soil density.

When assessing the physical properties of the soil at different depths in the families, significant differences were observed $(\mathrm{p}<0.05)$ (Table 5). For the Poaceae family, higher macroporosity $\left(0.08 \mathrm{~m}^{3} \cdot \mathrm{m}^{-3}\right)$ and lower soil density $(-0.15$ $\mathrm{Mg} \cdot \mathrm{m}^{-3}$ ) were found in the depth of $0-0.05 \mathrm{~m}$. In the Fabaceae family, there were significant differences $(p<0.05)$ only in soil density. This variation was inversely proportional to depth.

These results are justified by the higher concentration of root volume on the surface, about $66 \%$ [45], which are responsible for the approximation of soil particles. During their growth the roots exert pressure on the soil particles [46]; and also by the constant absorption of water from the soil profile [47], besides promoting the release of organic exudates that act as cementing agents [48] that contribute in the formation and stabilization of the aggregates improving the physical properties of the soil.

When evaluating the physical properties of the soil at different depths within the families, it was verified that the Poaceae presented higher macroporosity and lower soil density in the depth of $0-0.05 \mathrm{~m}$. At the same depth, the Fabaceae had the lowest soil density (Table 5).

The resistance of the soil to the penetration after the cultivation of different families of cover plants is shown in Figure 1. It was observed that in the area where the Poaceae was cultivated showed lower penetration resistance in relation to the Fabaceae, up to the depth of $0.20 \mathrm{~m}$. Different root systems have different capacities/forms of soil penetration.

As Poaceae by the intense proliferation of roots fasciculate in the arable layer of the soil [36], condition more aggregation and less resistance to penetration. On the other hand, in Fabaceae, about $80 \%$ of the pivotal root system are capable of reaching up to $0.80 \mathrm{~m}$ depth [49], which contributes to the reduction of penetration resistance below $0.20 \mathrm{~m}$.

In Figure 2, the influence on soil resistance to penetration after cultivation of cover plants within each of the evaluated families is presented. In the Poaceae family, black oats showed lower penetration resistance, differing significantly 
Resistance of soil to penetration (MPa)

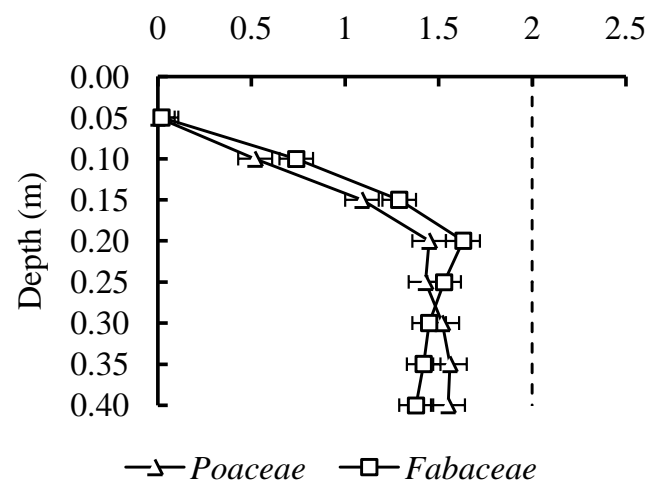

Figure 1. Average results for soil resistance to penetration in different families of cover plants and depths of evaluation.

Resistance of soil to penetration (MPa)

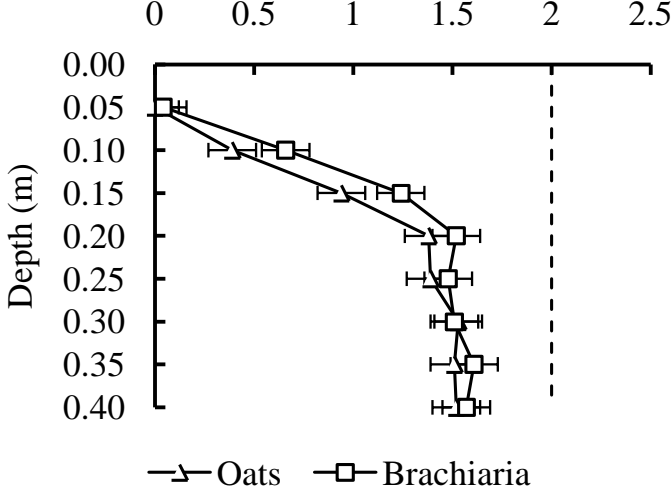

(a)

Resistance of soil to penetration (MPa)

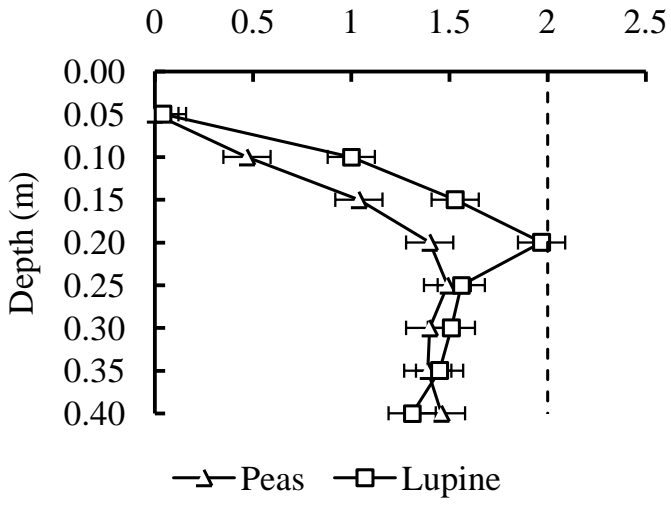

(b)

Figure 2. Average results for soil resistance to penetration within the different families of cover plants and depths of evaluation.

$(\mathrm{p}<0.05)$ from the brachiaria to the depth of $0.15 \mathrm{~m}$, below this depth there were no significant differences $(\mathrm{p}<0.05)$ (Figure $2(\mathrm{a})$ ). 
This result indicates that the highest dry mass increase of black oats (4966 $\mathrm{kg} \cdot \mathrm{ha}^{-1}$ ), associated to the most aggressive root system [50], was uniform and abundant throughout the soil volume [51], may have contributed to the increase in the stability of the larger diameter aggregates, improving soil structural quality [10], providing lower soil resistance to penetration.

For the Fabaceae (Figure 2(b)), soil resistance to penetration was found to be significantly different $(\mathrm{p}<0.05)$ between forage pea and white lupine up to a depth of $0.20 \mathrm{~m}$, with the lowest penetration resistance being evaluated in the cultivated area forage pea. However, in the treatment with white lupine at $0.20 \mathrm{~m}$ depth, the highest penetration resistance $(1.93 \mathrm{MPa})$ was observed, being very close to the value considered critical for most cultures, 2.0 MPa [52], But this limit can vary between $2-3 \mathrm{MPa}$ [53] as a function of soil moisture at the time of evaluation.

The physical properties evaluated in this experiment should be taken into consideration when choosing cover plants, especially when the purpose is to recover and/or improve the physical properties of the soil.

\section{Conclusions}

The Fabaceae family showed higher dry mass yield $\left(4400 \mathrm{~kg} \cdot \mathrm{ha}^{-1}\right)$, however, the lower soil cover rate $(68.71 \%)$.

The highest volume of macropores $\left(0.05 \mathrm{~m}^{3} \cdot \mathrm{m}^{-3}\right)$ and the lowest soil resistance to penetration were observed in the soil cultivated with Poaceae family cover plants, at the respective $0-0.10 \mathrm{~m}$ depth and $0.05-0.20 \mathrm{~m}$ depth.

\section{References}

[1] Argenton, J., Albuquerque, J.A., Bayer, C. and Wildner, L.P. (2005) Behavior of Attributes Related to the Shape of the Structure of Red Oxisolunder Preparation Systems and Cover Plants. Brazilian Journal of Soil Science, 29, 425-435.

[2] Bottega, E.L., Bottega, S.P., Silva, S.A., Queiroz, D.M., Souza, C.M.A. and Rafull, L.Z.L. (2011) Spatial Variability of Soil Resistance to Penetration in a Dystroferric Red Oxisol. Brazilian Journal of Agricultural Sciences, 6, 331-336.

[3] Müller, M.M.L., Ceccon, G. and Rosolem, C.A. (2001) Influence of Soil Compaction on Subsurface on Root Growth of Winter Green Manure. Brazilian Journal of Soil Science, 25, 531-538.

[4] Veiga, M., Horn, R., Reinert, D.J. and Reichert, J.M. (2007) Soil Compressibility and Penetrability of an Oxisol from Southern Brazil, as Affected by Long-Term Tillage Systems. Soil \& Tillage Research, 92, 104-113. https://doi.org/10.1016/j.still.2006.01.008

[5] Håkansson, I. (2005) Machinery-Induced Compaction of Arable Soils: Incidence, Consequences, Counter-Measures. Department Of Soil Sciences, Uppsala, Uppsala.

[6] Klein, V.A., Vieira, M.L., Durigon, F.F., Massing, J.P. and Fávero, F. (2008) Aeration Porosity of a Red Oxisol and Wheat Yield in Scarified No-Tillage. Rural Science, 38, 365-371. https://doi.org/10.1590/S0103-84782008000200011

[7] Canillas, E.C. and Salokhe, V.M.A. (2002) A Decision Support System for Compaction Assessment in Agricultural Soils. Soil \& Tillage Research, 65, 221-230. https://doi.org/10.1016/S0167-1987(02)00002-8 
[8] Severiano, E.C., Oliveira, G.C., Dias Junior, M.S., Costa, K.A.P., Castro, M.B. and Magalhães, E.N. (2010) Potential for Decomposition of an Argisol Promoted by Tifton Grass 85. Brazilian Journal of Agricultural and Environmental Engineering, $14,39-45$.

[9] Jimenez, R.L., Gonçalves, W.G., Araújo Filho, J.V., Assis, R.L., Pires, F.R. and Silva, G.P. (2008) Growth of Cover Plants under Different Compaction Levels in a Red Oxisol. Brazilian Journal of Agricultural and Environmental Engineering, 12, 116-121.

[10] Santos, G.G., Silveira, P.M., Marchão, R.L., Petter, F.A. and Becquer, T. (2012) Chemical Attributes and Stability of Aggregates under Different Cover Crops in Cerrado Oxisol. Brazilian Journal of Agricultural and Environmental Engineering, 16, 1171-1178.

[11] Rosa, H.A. (2013) Structural Potential of Cover Species in an Argiloso Latossolo and Its Reflections on Yield of Grains and Crambe Oil. Ph.D. Dissertation, State University of Western Paraná, Cascavel.

[12] Mendonça, V.Z., Mello, L.M.M., Andreotti, M., Pereira, F.C.B.L., Lima, R.C., Valério Filho, W.V. and Yano, E.H. (2013) Evaluation of the Physical Attributes of the Soil in Forage Consortium, Maize in Succession with Soybean in Cerrado Region. Brazilian Journal of Soil Science, 37, 251-259.

[13] Lima, V.M.P., Oliveira, G.C., Serafim, M.E., Curi, N. and Evangelista, E.R. (2012) Optimum Water Range as an Indicator of Improvement of the Structural Quality of Degraded Oxisol. Brazilian Journal of Soil Science, 36, 71-78.

[14] Williams, S.M. and Weil, R.R. (2004) Crop cover Root Channels May Alleviate Soil Compaction Effects on Soybean Crop. Soil Science Society American, 68, 1403-1409. https://doi.org/10.2136/sssaj2004.1403

[15] Fonseca, G.C., Carneiro, M.A.C., Costa, A.R., Oliveira, G.C. and Balbino, L.C. (2007) Physical, Chemical and Biological Attributes of Cerrado Distrófico Red Latosol under Two Crop Rotations. Tropical Agriculture Research, 37, 22-30.

[16] Negrini, A.C.A. (2007) Lettuce Performance (Lactuca sativa L.) Intercropped with Different Green Manures. PhD Dissertation, School of Agriculture "Luiz de Queiroz", University of São Paulo, Piracicaba.

[17] Loss, A., Basso, A., Oliveira, B.S., Koucher, L.P., Oliveira, R.A., Kurtz, C., Lovato, P.E., Curmi, P., Brunetto, G. and Comin, J.J. (2015) Total Organic Carbon and Soil Aggregation in Conventional Agroecological and Onion No-Tillage System. Brazilian Journal of Soil Science, 39, 1212-1224.

[18] Haynes, R.J. and Beare, M.H. (1997) Influence of Six Crop Species on Aggregate Stability and Some Labile Organic Matter Fractions. Soil Biology \& Biochemistry, 29, 1647-1653. https://doi.org/10.1016/S0038-0717(97)00078-3

[19] Coutinho, F.S., Loss, A., Pereira, M.G., Rodrigues Júnior, D.J. and Torres, J.L.R. (2010) Stability of Aggregates and Carbon Distribution in Latosol under No-Tillage System in Uberaba, Minas Gerais. Comunicata Scientiae, 1, 100-105.

[20] Silveira, P.M., Cunha, P.C.R., Stone, L.F. and Santos, G.G. (2010) Chemical Attributes of Cultivated Soil with Different Cover Crops. Tropical Agriculture Research, 40, 283-290.

[21] Caviglione, J.H., Kiihl, L.R.B., Caramori, P.H. and Oliveira, D. (2000) Climate Charts of Paraná. Londrina, Agronomic Institute of Paraná (IAPAR).

[22] Santos, H.G., Almeida, J.A., Lumbreras, J.F., Anjos, L.H.C., Coelho, M.R., Jacomine, P.K.T., Cunha, T.J.F. and Oliveira, V.A. (2013) Brazilian System of Soil Classification. Brazilian Agricultural Research Corporation (EMBRAPA), Brasília. 
[23] Raij, B.V., Andrade, J.C., Cantarella, H. and Quaggio, J.A. (2001) Chemical Analyzes for Fertility Evaluation of Tropical Soils. Instituto Agronômico, Campinas.

[24] EMBRAPA (1997) Manual of Methods of Soil Analysis. Brazilian Agricultural Research Corporation (EMBRAPA), Rio de Janeiro.

[25] Laflen, J.M., Amemiya, M. and Hintz, E.A. (1981) Measuring Crop Residue Cover. Journal of Soil and Water Conservation, 36, 341-343.

[26] Ferreira, D.F. (2011) Sisvar: A Computer Statistical Analysis System. Science and Agrotechnology, 35, 1039-1042. https://doi.org/10.1590/S1413-70542011000600001

[27] Souza, J.L. and Guimarães, G.P. (2013) Mass Fertilizer Yield and the Impact on Soil Fertility in Succession of Organic Crops. Bioscience Journal, 29, 1796-1805.

[28] Ziech, A.R.D., Conceição, P.C., Luchese, A.V., Balin, N.M., Candiotto, G. and Garmus, T.G. (2015) Soil Protection by Winter Cover Crops in Southern Brazil. Brazilian Agricultural Research, 50, 374-382.

[29] Kliemann, H.J., Magalhães, R.T., Oliveira, I.P. and Moraes, M.F. (2003) Relationships of the Production of Green Mass of Brachiaria brizantha with Nutrient Availability Indexes in Soils under the Barreirão System of Management. Tropical Agriculture Research, 33, 49-56.

[30] Amado, T.J.C., Mielniczuk, J. and Aita, C. (2002) Nitrogen Fertilization Recommendation for Corn in RS and SC Adapted to the Use of Cover Crops under No-Tillage System. Brazilian Journal of Soil Science, 26, 241-248.

[31] Silva, T.C., Macedo, C.H.O., Araújo, S.S., Pinho, R.M.A., Perazzo, A.F., Santos, E.M. and Gonzaga Neto, S. (2011) Agronomic Characteristics of Brachiaria decumbens Grass Submitted to Cutting Intensities and Frequencies and Nitrogen Fertilization. Brazilian Journal of Animal Health and Production, 12, 583-593.

[32] Ceretta, C.A., Basso, C.J., Herbes, M.G., Poletto, N. and Silveira, M.J. (2002) Phytomass Production and Decomposition of Winter Cover Crops and Corn, under Different Management of Nitrogen Fertilization. Rural Science, 32, 49-54. https://doi.org/10.1590/S0103-84782002000100009

[33] Aita, C. and Giacomini, S.J. (2003) Decomposition and Release of Nitrogen from Cultural Residues of Single and Intercropped Soil Cover Plants. Brazilian Journal of Soil Science, 27, 601-612.

[34] Seidel, E.P., Mattia,V., Mattei, E. and Corbari, F. (2015) Dry Matter Production and Soil Physical Properties in Corn and Brachiaria Consortium. Scientia Agraria Paranaensis, 14, 18-25. https://doi.org/10.18188/1983-1471/sap.v14n1p18-24

[35] Pickler, E.P., Nóbrega, L.H.P., Lima, G.P., Konopatzki, M.R.S. and Pacheco, F.P. (2012) Influence of Winter Cover on Physical Attributes of Soil in Corn and Soybean under No-Tillage. Engineering in Agriculture, 20, 33-45.

[36] Kondo, M.K., Albuquerque, C.J.B., Wendling, B., Silva, P.B. and Cardoso, M.M. (2012) Effect of Plant Cover on Soil Physical Attributes and Agronomic Characteristics of Sorghum. Bioscience Journal, 28, 33-40.

[37] Fidalski, J. and Tormena, C.A. (2007) Homogeneity of the Physical Quality of the Soil between the Lines of an Orange Orchard with Permanent Vegetation Management Systems. Brazilian Journal of Soil Science, 31, 637-645.

[38] Eden, M., Schjonning, P., Moldrup, P. and Jonge, L.W. (2011) Compaction and Rotovation Effects on Soil Pore Characteristics of a Loamy Sand Soil with Contrasting Organic Matter Content. Soil Use and Management, 27, 340-349. https://doi.org/10.1111/j.1475-2743.2011.00344.x

[39] Bonetti, J.A., Paulino, H.B., Souza, E.D., Carneiro, M.A.C. and Silva, G.N. (2015) 
Influence of the Integrated System of Agricultural Production on the Soil and Yield of Soybean and Brachiaria. Tropical Agriculture Research, 45, 104-112.

[40] Medeiros, A.R., Câmara Júnior, C.L., Pereira, J.O., Oliveira, F.A. and Amaro Filho, J. (2015) Evaluation of Soil Compaction by Means of an Oedometric Test. Green Magazine on Agroecology and Sustainable Development, 10, 9-22.

[41] Viana, E.T., Batista, M.A., Tormena, C.A., Costa, A.C.S. and Inoue, T.T. (2011) Physical Attributes and Organic Carbon in Red Oxisol under Different Systems of Use and Management. Brazilian Journal of Soil Science, 35, 2105-2114.

[42] Neto, E.L.S., Andrioli, I., Beutler, A.N. and Centurion, J.F. (2008) Soil Physical Attributes and Maize Yield in Response to Pre-Harvest Crops. Brazilian Agricultural Research, 43, 255-260.

[43] Reichert, J.M., Reinert, D.J. and Braida, J.A. (2003) Soil Quality and Sustainability of Agricultural Systems. Science and Environment, 27, 29-48.

[44] Reinert, D.J., Reichert, J.M. and Silva, V.R. (2001) Soil Physical Properties in Irrigated No-Tillage System. In: Carlesso, R., Petry, M.T., Rosa, G.M. and Ceretta, C.A., Eds., Sprinkler Irrigation in Rio Grande do Sul, Federal University of Santa Maria, Santa Maria, 114-133.

[45] Silveira, F.P.M., Silva, I.F., Souza, R.F., Santiago, R.D. and Rocha, I.T.M. (2015) Dry Mass of the Cespitoso and Decumbent Root System of Brachiaria in Different Conditions. In: 35 th Brazilian Congress of Soil Science, The Soil and Its Multiple Functions, Brazilian Society of Soil Science (SBCS), Natal.

[46] Guedes Filho, O., Silva, A.P., Giarola, N.F.B. and Tormena, C.A. (2013) Structural Properties of the Soil Seedbed Submitted to Mechanical and Biological Chiseling under No-Tillage. Geoderma, 204-205, 94-101. https://doi.org/10.1016/j.geoderma.2013.04.017

[47] Silva, I.F. and Mielniczuk, J. (1997) Action of the Root System of Plants in the Formation and Stabilization of Soil Aggregates. Brazilian Journal of Soil Science, 21, 113-117.

[48] Calonego, J.C. and Rosolem, C.A. (2008) Stability of Soil Aggregates after Crop Rotation and Scarification. Brazilian Journal of Soil Science, 32, 1399-1407.

[49] Silva, J.A.M., Gomes, T.C.A., Soares, E.M.B., Sá, P.G., Silva, M.S.L. and Faria, C.M.B. (2002) Characterization of Root Systems of Legumes Grown under Irrigation in the São Francisco Valley: 1. Distribution Pattern. In: 14th Brazilian Meeting on Soil and Water Management and Conservation, Brazilian Agricultural Research Corporation (EMBRAPA), Cuiabá.

[50] Lopes, H.J., Weber, F.S., Guilherme, V., Salvador, R., Valicheski, R.R. and Stürmer, S.L.K. (2013) Mechanical Soil Resistance to Penetration and Yield of Corn under Different Cover Crops and Nitrogen Rates. In: VI National Exhibition of Interdisciplinary Scientific and Technological Initiation, Federal Institute of Santa Catarina, Camboriú.

[51] Costa, P.F. (2014) Management of Winter Crops and Their Influence on Soil Physical Properties, Weed Dynamics, Nutrient Content and Accumulation. PhD Dissertation, State University of the West of Paraná, Marechal Cândido Rondon.

[52] Santos, M.H.F., Ribon, A.A., Fernandes, K.L., Silva, O.C.C., Oliveira, L.C. and Silva, A.A. (2015) Estimation of Compaction through Soil Resistance to Soil Penetration under Different Crops and Native Forest. Electronic scientific journal of Agronomy, 27, 49-62.

[53] Imhoff, S., Silva, A.P. and Tormena, C.A. (2000) Applications of the Resistance Curve in the Physical Quality Control of Soil under Pasture. Brazilian Agricultural Research, 35, 1493-1500. 